\title{
NOTE
}

\section{RECOMMENDATIONS ON THE OPTIMAL CONSTITUTIONAL RECOGNITION OF THE First Nations in AUStralia}

\section{Benjamen FrankLen Gussen*}

This note extends my previous analysis of the constitutional recognition of Aboriginal and Torres Strait Islander Peoples ('First Nations') by providing guidance on the optimal approach for this recognition. The guidance is founded on the concepts of efficiency and equity. An optimal recognition is defined as one that achieves both objectives simultaneously. Efficiency flows from a dynamic recognition that changes over time relatively easily, as exemplified by a treaty-based approach. The equity criterion has, as a proxy, legal pluralism, whereby constitutional recognition enlivens 'Indigenous jurisprudence' through mechanisms such as self-governance. The proposal is to combine efficiency and equity by guaranteeing the collective rights of Indigenous Australians in accordance with universally recognised principles and norms of international law, such as the UN Declaration on the Rights of Indigenous Peoples (for which the Commonwealth of Australia announced its support in 2009). This in turn is likely to guide a treaty-based approach to the relationship between the Commonwealth and First Nations that can evolve towards legal pluralism.

\section{INTRODUCTION}

This note focuses on the ideal implementation of a constitutional recognition of First Nations. ${ }^{1}$ The intention is to provide guidance on the best approach to such

\footnotetext{
* BCom (Hons), LLB (Hons), PhD (Auckland), MBA (Otago), Lecturer, Faculty of Business and Law, Swinburne Law School, Swinburne University. The author would like to thank the DLR editors, especially Dr Claudio Bozzi, for their generous comments on this manuscript.

${ }^{1}$ For a detailed analysis of approaches to constitutional recognition in Canada, New Zealand, Bolivia and the Ecuador, see Benjamen Franklen Gussen, 'A Comparative Analysis of
} 
a constitutional recognition, assuming the existence of the required political volition not only to enact the same but to ensure that envisaged benefits flow through to the First Nations in Australia. Given the legal focus of the paper, it is not unreasonable to make this assumption.

The note is structured as follows. The rest of this introduction looks at the recent developments in the drive for recognition, and the current proposals for constitutional change. The second Part introduces the analytical framework for choosing the optimal design. The third Part furnishes my recommendations based on the optimal design identified in the previous Part. These recommendations include the proposed wording for a new chapter in the Australian Constitution, and recommendations on sections 25 (provisions as to races disqualified from voting) and 51(xxvi) (the race power), as well as comments on the sections proposed by the Expert Panel on Constitutional Recognition of Indigenous Australians, namely sections 116A (prohibition of racial discrimination) and $127 \mathrm{~A}$ (recognition of languages). The note ends, in Part IV, with a synopsis of the findings and some ruminations on directions for further research.

\section{A Recent Developments in the Drive for Recognition}

Part of the impetus for the current drive for a constitutional recognition of the First Nations in Australia came from the Aboriginal and Torres Strait Islander Peoples Recognition Act 2013 (Cth) ('Recognition Act').

The conversation began with the Expert Panel on Constitutional Recognition of Indigenous Australians ('the Expert Panel') established in December 2009 by the then Prime Minister of Australia, Julia Gillard. Its role was to consult on the 'best possible options for a constitutional amendment'2 on the recognition of First Nations to be put to a referendum. The Expert Panel concluded in 2012 that the recognition 'would be incomplete without a constitutional prohibition of laws that discriminate on the basis of race'. ${ }^{3}$ The Expert Panel Final Report

\footnotetext{
Constitutional Recognition of Aboriginal Peoples' (2017) 40(3) Melbourne University Law Review 867 ('A Comparative Analysis').

${ }^{2}$ Expert Panel on Constitutional Recognition of Indigenous Australians, Recognising Aboriginal and Torres Strait Islander Peoples in the Constitution: Report of the Expert Panel, January 2012 ('Expert Panel Final Report') 1 <https://www.pmc.gov.au/resource-centre/indigenousaffairs/final-report-expert-panel-recognising-aboriginal-and-torres-strait-islander-peoplesconstitution>.

${ }^{3}$ Ibid 167.
} 
is currently recognised as 'the most detailed recent discussion on constitutional recognition'. ${ }^{4}$

The conversation continued with the report of the Joint Select Committee on Constitutional Recognition of Aboriginal and Torres Strait Islander Peoples 'Joint Select Committee'), a Parliamentary committee established at the end of 2013 whose role was to build a 'secure strong multi-partisan parliamentary consensus' ${ }^{5}$ on the next steps towards Indigenous constitutional recognition. The options for constitutional reform put forward by the Joint Select Committee included a form of prohibition of racial discrimination. The Joint Select Committee had heard evidence that the prohibition 'is considered necessary in order to provide substantive reform'. 6

In 2014, under the Recognition Act, the Minister for Indigenous Affairs appointed a Review Panel to assess 'levels of public awareness and support for amending the Constitution to recognise Indigenous peoples and levels of community support for different proposals for constitutional change'. ${ }^{7}$ It reported in September the same year. ${ }^{8}$

The most recent proposals for Indigenous constitutional recognition are set out in the Referendum Council's Final Report ('Referendum Council Final Report' $)^{9}$ which was issued in June 2017 and to which the then Prime Minister, Malcolm Turnbull, responded in October 2017. ${ }^{10}$ The Referendum Council had been established by Mr Turnbull and the then leader of the Opposition, Bill

\footnotetext{
${ }^{4}$ Referendum Council, Discussion Paper on Constitutional Recognition of Aboriginal and Torres Strait Islander Peoples, October 2016 ('Referendum Council Discussion Paper') 6 $<$ https://www.pmc.gov.au/sites/default/files/publications/Referendum-Council-DiscussionPaper-Oct2016.pdf>.

${ }^{5}$ Joint Select Committee on Constitutional Recognition of Aboriginal and Torres Strait Islander Peoples, Parliament of Australia, Final Report (June 2015) ('Joint Select Committee Final Report') 1 <https://apo.org.au/sites/default/files/resource-files/2015/06/apo-nid555041182366.pdf>.

${ }^{6}$ Ibid 63 (emphasis added).

${ }^{7}$ Commonwealth of Australia, Review Panel of the Aboriginal and Torres Strait Islander Act, Final Report (2014) 5 ('Review Panel Final Report') 9 <https://www.pmc.gov. $\mathrm{au} /$ sites/default/files/publications/Final_Report_Aboriginal_Torres_Strait_Islander_Act_of_R ecognition_Review_Panel.pdf $>$.

${ }^{8}$ Ibid.

${ }^{9}$ Referendum Council, Final Report of the Referendum Council, July 2017 ('Referendum Council Final Report') <https://www.referendumcouncil.org.au/sites/default/files/report_attachments/ Referendum_Council_Final_Report.pdf $>$.

10 Malcolm Turnbull, Media Release: Response to Referendum Council's Report on Constitutional Recognition (26 October 2017) <https://www.malcolmturnbull.com.au/ media/response-to-referendum-councils-report-on-constitutional-recognition>.
} 
Shorten, in December 2015 to '[1]ead the process for national consultations and community engagement about constitutional recognition, including a concurrent series of Indigenous designed and led consultations'. ${ }^{11}$ The Referendum Council recognised the Joint Select Committee's prohibition of racial discrimination as a 'substantive proposal', ${ }^{12}$ however viewed its protection against adverse discrimination 'as a shield dependent upon interpretation by the High Court of Australia'. ${ }^{13}$ The Referendum Council's Final Report compared the Joint Select Committee's prohibition proposal to its own proposal that a body be established to act as an Indigenous 'Voice to the Parliament' ${ }^{14}$ While the two proposals were put forth as alternatives to each other, ${ }^{15}$ the Referendum Council's Final Report stated that the Delegates to the First Nations Regional Dialogues preferred the 'Voice to the Parliament' option, which they viewed 'as a sword, enabling First Peoples to advocate directly to the Parliament'. ${ }^{16}$

\section{B Proposals for Constitutional Change}

The Review Panel of the Aboriginal and Torres Strait Islander Act, in its 2014 final report, had addressed the nature of the proposition to be put to the Australian people in any referendum:

Crystallising the question to be put to the Australian voters lies at the heart of the referendum. Indeed, shaping a final proposition is by far the most complex matter on the path to a referendum. Definitively assessing the country's readiness for a referendum is difficult in the absence of the final proposal to be put to a vote. ${ }^{17}$

The Panel had narrowed the desired constitutional amendments to three main elements:

1. the placement of a statement of recognition;

\footnotetext{
${ }^{11}$ Referendum Council Final Report (n 9) 3.

${ }^{12}$ Ibid 13.

${ }^{13}$ Ibid (emphasis added).

${ }^{14}$ Ibid.

${ }^{15}$ Ibid.

${ }^{16}$ Ibid (emphasis added).

${ }^{17}$ Review Panel Final Report (n 7) 5.
} 
2. the removal of section 25 'which currently envisages the ability of state governments to disqualify a group of people from voting based on race'; and

3. the re-formulation of section 51(xxvi). ${ }^{18}$

While this note addresses each one of these elements, it gives most attention to the first element. The analysis in this note suggests that current proposals for the recognition of First Nations are suboptimal as they are neither sufficiently wide (addressing the sui generis nature of Indigenous collective rights from within Indigenous jurisprudence ${ }^{19}$ nor sufficiently dynamic (allowing for evolutionary improvement) to meet the objectives of efficiency (in terms of the input needed to bring about constitutional amendments) and equality (in terms of affording Indigenous Australians the same development opportunities afforded to non-Indigenous Australians as required under international law standards). Instead, this note advocates a form of constitutional recognition that links the jurisprudence on governance structures for First Nations in Australia to existing international law standards, with a proviso that such recognition must be kept within the limits envisaged in the Australian Constitution. ${ }^{20}$

As to the second and third elements listed above, the note recommends a laissez-faire approach whereby existing sections are left as they are, and constitutional amendment through the introduction of new sections is minimised. This would simplify the changes brought about by the recognition, and would hence improve the chances of the proposed amendments being passed by voters.

The note assumes a present and continuing political will on the part of government to give effect to a constitutional recognition of First Nations. The note does not entertain the myriad of issues that would result from a government's cynical approach to such recognition - if the recognition were simply a 'window dressing' exercise driven by external pressures, or if later governments decided to slow down progress flowing from such recognition. Instead the focus is on the ideal implementation of a constitutional recognition. The intention is to provide guidance on the best approach to constitutional recognition, assuming the existence of the required political will not only to

\footnotetext{
${ }^{18}$ Ibid. Compare this with the type of recognition given in the Aboriginal and Torres Strait Islander Peoples Recognition Act 2013 (Cth) s 3.

${ }^{19}$ The term is used in this note to describe a complete legal system that, like Islam or Tikanga Maori, did not originate in Europe. In Australia, First Nations have such a system originating from their religion or mythology.

${ }^{20}$ Commonwealth of Australia Constitution Act 1900 (Imp) s 9. See Part III, below.
} 
enact the same, but to ensure that the envisaged benefits arising from implementing such a recognition flow through to First Nations. The implications of constitutional recognition will be considered with an eye to the effects that recognition may have on existing political arrangements. ${ }^{21}$

The note is structured as follows. Part II provides the analytical framework for the present discussion. The analysis identifies an optimal approach to constitutional recognition that provides guidance in the Australian context.

The final Part (Part III) uses the normative signals from the analytical model to design a proposal for a constitutional recognition of First Nations in Australia. The Part also provides guidance on other proposed amendments, including those pertaining to sections 25 and 51(xxvi) of the Australian Constitution.

\section{The Analytical Framework}

The analytical model ${ }^{22}$ depicted in Figure 1 below has two dimensions plotted along conventional $\mathrm{x}$ [horizontal] and $\mathrm{y}$ [vertical] axes. The first dimension on the $\mathrm{x}$ [horizontal] axis represents scope and gauges the wide versus narrow nature of the recognition. This dimension is a proxy for legal pluralism, with a narrow form of recognition promoting minimal pluralism. This narrow recognition eschews collective rights in favour of assimilating First Nations' rights under a paradigm of individual rights. This limitation prevents any transition to legal pluralism, a fact which in turn is likely to weaken the prospects of improving the wellbeing of First Nations since it moulds their socio-economic development outside their own jurisprudence. ${ }^{23}$ In contrast, a wide recognition emphasises the collective nature of First Nations' rights and enables plurinationalism (the co-existence of several different nationalities

\footnotetext{
${ }^{21}$ This is done, albeit briefly, in Part II.

${ }^{22}$ For earlier versions of this model, refer to Benjamen Franklen Gussen, 'A Comparative Analysis of Constitutional Recognition of Aboriginal Peoples' (2017) 40(3) Melbourne University Law Review 867; Benjamen Franklen Gussen, 'Constitutional Recognition of Indigenous Peoples in New Zealand and Ecuador' in Simon Young, Jennifer Nielsen and Jeremy Patrick (eds), Constitutional Recognition of First Peoples in Australia: Theories and Comparative Perspectives (Federation Press, 2016).

${ }^{23}$ Rights in First Nation jurisprudence are generally collective in nature. In contrast, individual rights dominate Western jurisprudence. Hence, small groups, such as the family or the tribe, are the dominant scale in the former for assigning liability. For further clarification of this point, please see for example, Megan Davis, 'Recognition of Aboriginal and Torres Strait Islander Rights' (2006) 5 Journal of Indigenous Policy 35 and Alexandra Xanthaki, 'Collective Rights: The Case of Indigenous Peoples' (2000) 25 Amicus Curiae 7.
} 
within one polity) 24 $^{4}$ and subsidiarity (giving lower levels of social organisation, such as the city, church, or tribe, a constitutional space (that is, a margin of discretion in governance) $)^{25}$ to inform the design of First Nations governance structures. ${ }^{26}$

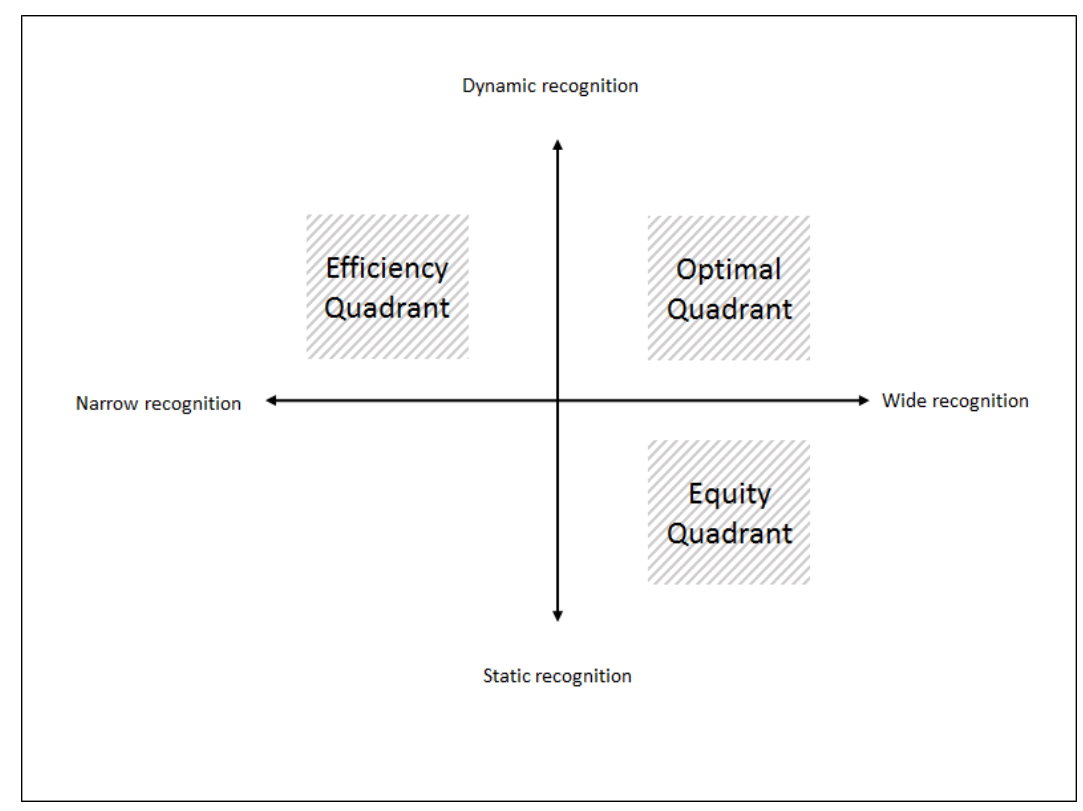

Figure 1: Analytical model showing two dimensions and the corresponding objectives of efficiency and equity. The optimal quadrant represents a union of the objectives of efficiency and equity. The quadrant to the bottom left is sub-optimal in that narrow and static recognition will reduce both efficiency and equity.

${ }^{24}$ For a better understanding of how plurinationalism works, see Ramón Masnou Boixeda, Notes on Nationalism (Gracewing, 2002). See also Roger Merino, 'Reimagining the Nation-State: Indigenous Peoples and the Making of Plurinationalism in Latin America' (2018) 31(4) Leiden Journal of International Law 773.

${ }^{25}$ For more on the principle of subsidiarity, see Benjamen Gussen, Axial Shift: City Subsidiarity and the World System in the 21st Century (Palgrave Macmillan, 2019).

${ }^{26}$ For examples of multinationalism refer to Eduardo Silva, 'Indigenous Peoples' Movements, Developments, and Politics in Ecuador and Bolivia' in Paul Almeida and Allen Cordoro Ulate (eds), Handbook of Social Movements across Latin America (Springer, 2015) 131. On the principle of subsidiarity see Benjamen F Gussen, 'Is Subsidiarity a Conditio Sine Qua Non for Sustainability?' (2015) 36(4) Policy Studies 384, and Benjamen F Gussen, 'Subsidiarity as a Constitutional Principle in New Zealand' (2014) 12(1) New Zealand Journal of Public and International Law 123. 
The second dimension, measured on the y [vertical] axis, represents time and evolution. ${ }^{27}$ It gauges the dynamic versus static nature of the recognition. This dimension is a useful measure in cases of treaty-formation between the recogniser (for example the Crown) and the recognised (First Nations). A recognition is static when there is considerable inertia or reluctance to change, either due to an onerous amendment process, or to the specificity with which the constitution has limited the rights flowing from the recognition - for example through enumeration of these rights. ${ }^{28}$ On the other hand, a recognition is dynamic in cases where there is a variety of ways through which the recognition can be actioned. Hence, an approach where the recognition is with respect to 'subject matter' is more static than a recognition with reference to a so-called 'persons power'. ${ }^{29}$ To be clear, section 51(xxvi) (the race power), section 51(xix) (the aliens power), and section 51(xx) (the corporations power) of the Australian Constitution are 'persons powers' because they require 'the law to deal with things or activities which help to differentiate or identify the persons referred to in the power from other persons who are not referred to in the power' ${ }^{30}$ It should be noted that the capacity for evolution is more important than the scope of the constitutional recognition. Over the long run, accumulated quantitative change brought about by a dynamic recognition (for example, through the formation of treaties between First Nations and the Commonwealth) is likely to lead to qualitative change that widens the constitutional recognition in favour of drivers of First Nations jurisprudence

\footnotetext{
${ }^{27}$ Evolution in my framework means an increase in complexity, which is turn is an increase in scale. Scale itself is produced as a result of symmetry breaking. In this sense, evolution can be understood as energy dispersal or distribution (ie, entropy which is analogous to symmetry). A change is energy distribution signifies evolution. See Benjamen Gussen, Axial Shift: City Subsidiarity and the World System in the 21 st Century (Palgrave Macmillan, 2019) 177-90.

${ }^{28}$ See, for example, article 30(II)(14) of the Constitution of Bolivia of 2009 that recognises the right of First Nations ' $[\mathrm{t}]$ o practice .... their political, juridical and economic systems in accord with their world view'. See Benjamen Franklen Gussen, 'A Comparative Analysis of Constitutional Recognition of Aboriginal Peoples' (2017) 40(3) Melbourne University Law Review 867.

${ }^{29}$ Joint Select Committee on Constitutional Recognition of Aboriginal and Torres Strait Islander Peoples, Parliament of Australia, Interim Report (July 2014) [2.35]-[2.43] ('Joint Select Committee Interim Report'), discussing subject matter powers <http://www. reconciliationsa.org.au/assets/media/files/Interim_report[2].pdf >; Joint Select Committee Final Report (n 5) [3.19]-[3.20] relating to the retention of the 'persons power'. See also Anne Twomey, 'A Revised Proposal for Indigenous Constitutional Recognition' (2014) 36(3) Sydney Law Review 381. For problems with the 'subject matter' approach see Rosalind Dixon and George Williams, 'Drafting a Replacement for the Races Power in the Australian Constitution' (2014) 25 Public Law Review 85.

${ }^{30}$ Geoffrey Lindell, 'The Corporations and Races Powers' (1984) 14(3) Federal Law Review $219,220$.
} 
such as subsidiarity and thus leads to a plurinational approach to governance. An example of this possibility is the recognition of First Nations in Canada. ${ }^{31}$

The optimal approach results from combining the two dimensions as shown in Figure 1 above. When a (second quadrant) narrow-dynamic recognition is opted for, there is an emphasis on efficiency. The focus is on reducing the costs flowing from constitutional recognition by keeping the input requirements for the recognition, such as the cost of treaty-negotiations that could lead to subsidiarity and plurinationalism, to a minimum. This economy is usually achieved by ignoring legal pluralism and recognising only individual rights. This deficiency in designing the recognition leads to lower welfare expectations initially, relative to the first quadrant approach, although these expectations can progress gradually over time. ${ }^{32}$ In contrast, a (fourth-quadrant) wide-static recognition emphasises equality and the benefits that derive from the recognition. A wide recognition can afford First Nations legal pluralism, but the cost could be prohibitive. Therefore, a cap in the form of a static recognition is imposed by weakening possibilities for progress to non-enumerated rights, and a strategy of subsidiarity (in the form of transferring more competencies and discretion to First Nations) is adopted. The responsibility for meeting the costs of a wider recognition is delegated to First Nations.

\section{Recommendations}

My proposed approach to constitutional recognition in Australia is to combine the efficiency (treaty-based approach) as seen, for example, in Canada and New Zealand with the equity (legal pluralism approach) as seen, for example, in Ecuador and Bolivia. ${ }^{33}$ While it is not always possible to achieve efficiency and equity simultaneously (as the one is focused on inputs and the other on outputs), it is possible in the present case to combine the two in a 'staggered' fashion where both efficiency and equity occur, but not at the same time. The proposal is for a recognition that guarantees the collective rights of First Nations in accordance with universally recognised principles and norms of international

${ }^{31}$ For a detailed analysis of the approach in Canada, see Benjamen Franklen Gussen, 'A Comparative Analysis of Constitutional Recognition of Aboriginal Peoples' (2017) 40(3) Melbourne University Law Review 867. This evolutionary approach contemplates processes such as treaty re-interpretation by the courts (NZ), or treaty renegotiation (replacing the treaty in its entirety). Both processes are evolutionary in their time scale - taking centuries. The envisaged evolution does not assume that the treaty is open to being better informed, open to revision/amendment/sunsetting, or that revision procedures are part of the treaty, and so forth.

${ }^{32}$ As seen in Canada.

${ }^{33}$ A full analysis of the constitutional recognition of First Nations in these four jurisdictions is provided in Gussen, 'A Comparative Analysis' (n 1). 
law, such as the UN Declaration on the Rights of Indigenous Peoples ${ }^{34}$ (for which the Commonwealth of Australia announced its support in 2009). ${ }^{35}$ This in turn is likely to see the relationship between the Commonwealth and First Nations evolve towards a treaty-based approach similar to that of New Zealand and Canada. What is envisaged is a series of treaties between the Indigenous communities and the Commonwealth.

To be able to combine efficiency and equity, the recognition would have to refer to legal standards outside the Australian Constitution, such as standards embodied in treaties that envisage legal pluralism, for example through selfdetermination. The proposal is for treaties between the Crown (in right of the Commonwealth) and First Nations that recognise (hard and soft) international law instruments in relation to First Nations and other minorities. These instruments include: the United Nations Charter (which requires fundamental freedom for all without distinction as to race, sex, language, or religion); ${ }^{36}$ the 1992 UN Declaration on the Rights of Persons Belonging to National, Ethnic, Religious and Linguistic Minorities ${ }^{37}$ the UN Declaration on the Rights of Indigenous People, ${ }^{38}$ the International Labour Organization Convention on Indigenous and Tribal Peoples (Convention No 169); ${ }^{39}$ the UN Convention on the Elimination of All Forms of Racial Discrimination; ${ }^{40}$ the Declaration on the Elimination of All Forms of Discrimination Based on Religion or Belief; ${ }^{41}$ the UNESCO Universal Declaration on Cultural Diversity; ${ }^{42}$ the International Covenant on Civil and Political Rights ${ }^{43}$ and the International Convention on

\footnotetext{
${ }^{34}$ United Nations Declaration on the Rights of Indigenous Peoples, GA Res 61/295, UN Doc A/RES/61/295 (2 October 2007, adopted 13 September 2007).

${ }^{35}$ Michael Dodson, 'Australian Government Announcement on the UN Declaration on the Rights of Indigenous Peoples' (Government Announcement, 3 April 2009) <https://ncis. anu.edu.au/_lib/doc/MD_statement_Aust_Govt_endorsement_Dec_RIPs_19-30apr10.pdf>.

${ }^{36}$ Charter of the United Nations art 1(3).

${ }^{37}$ Declaration on the Rights of Persons Belonging to National, Ethnic, Religious and Linguistic Minorities, GA Res 47/135 (18 December 1992).

${ }^{38}$ Above n 34.

${ }^{39}$ Convention concerning Indigenous and Tribal Peoples in Independent Countries, opened for signature 27 June 1989, 1650 UNTS 383 (entered into force 5 September 1990).

40 International Convention on the Elimination of All Forms of Racial Discrimination, opened for signature 21 December 1965, 660 UNTS 195 (entered into force 4 January 1969).

${ }^{41}$ Declaration on the Elimination of All Forms of Intolerance and of Discrimination Based on Religion or Belief, GA Res 36/55, UN GAOR, $36^{\text {th }}$ Sess, Supp No 51, UN Doc A/36/684 (1981) 171.

${ }^{42}$ Universal Declaration on Cultural Diversity, General Conference of UNESCO, $31^{\text {st }}$ Sess (2 November 2001) art 4.

${ }^{43}$ International Covenant on Civil and Political Rights, opened for signature 16 December 1966, 999 UNTS 171 (entered into force 23 March 1976) art 27.
} 
Economic, Social, and Cultural Rights. ${ }^{44}$ Since the 1960s the international law paradigm has shifted from one of assimilation to one of diversity. This can be seen by comparing the International Labour Organization (ILO) Indigenous and Tribal Populations Convention, 1957 (No 107 of 1957) ${ }^{45}$ with its revised version, the abovementioned Convention on Indigenous and Tribal Peoples (No 169 of 1989). ${ }^{46}$ The Preamble to the 1989 Convention stresses control by First Nations of their own institutions, while the Preamble to the 1957 Convention used the language of 'protection and integration of indigenous [peoples]' and was based on the assumption that Indigenous peoples would disappear with modernisation. ${ }^{47}$ The current international human rights regime instead advances a 'plurinational' model. ${ }^{48}$

Inspiration from international law on First Nations is already a factor pressing towards constitutional evolution in Australia, not only through the High Court interpretation of the Commonwealth Constitution, but also, and as effectively, through the political pressure on Australia to take its rightful place as a world leader. Submissions to the Joint Select Committee ${ }^{49}$ have already referred the Committee to the recognition of Indigenous peoples in international law, in particular in the United Nations Declaration on the Rights of Indigenous Peoples. ${ }^{50}$ Moreover, in its 1992 Mabo v Queensland decision,,${ }^{51}$ the High Court

${ }^{44}$ International Covenant on Economic, Social and Cultural Rights, opened for signature 16 December 1966, 993 UNTS 3 (entered into force 3 January 1976).

45 Convention concerning the Protection and Integration of Indigenous and Other Tribal and Semi-Tribal Populations in Independent Countries, adopted 26 June 1957, 328 UNTS 248 (entered into force 2 June 1959) ('Convention concerning the Protection and Integration of Indigenous and Other Tribal and Semi-Tribal Populations').

${ }^{46}$ Above $\mathrm{n} 39$.

${ }^{47}$ Convention concerning the Protection and Integration of Indigenous and Other Tribal and Semi-Tribal Populations (n 45) Preamble.

${ }^{48}$ See Jost Delbrück 'Structural Changes in the International System and its Legal Order: International Law in the Era of Globalization' (2001) 11 Schweizerische Zeitschrift für internationales und europäisches Recht 1; Francisco Lopez Bermudez, 'Indigenous Peoples and International Law: The Case of Ecuador' (1997) 10(1) St Thomas Law Review 175; Stephen Tierney, 'Reframing Sovereignty? Sub-State National Societies and Contemporary Challenges to the Nation-State' (2005) 54(1) International and Comparative Law Quarterly 161.

${ }^{49}$ For example, Law Council of Australia, Submission No 288 to the Joint Select Committee on Constitutional Recognition relating to Aboriginal and Torres Strait Islander Peoples, Constitutional Recognition Relating to Aboriginal and Torres Strait Islander Peoples (15 June 2018). Submissions can be found at 'Submissions Received by the Committee', Parliament of Australia (Web Page) <https://www.aph.gov.au/Parliamentary_Business/Committees/Joint/ Former_Committees/Constitutional_Recognition_2018/ConstRecognition/Submissions>.

${ }^{50}$ The proposed constitutional recognition follows Australia's adoption in 2009 of the United Nations Declaration on the Rights of Indigenous Peoples (n 34).

${ }^{51}$ Mabo v Queensland (No 2) (1992) 175 CLR 1. 
relied on the International Covenant on Civil and Political Rights and its prohibition of unjust discrimination. ${ }^{52}$ There are many other instances where Australian constitutional law has developed in unison with international law instruments (and not only in relation to First Nations) largely through the application of the section 51(xxix) 'external affairs' power. ${ }^{53}$ Mabo suggests the emergence of a school of constitutional interpretation that converges towards the general principles of customary international law, to the extent possible, without conflict with legislation or common law.

The treaties that I propose between the First Nations and the Commonwealth could be viewed, from the perspective of legal pluralism, as treaties between sovereigns or different nations and hence as international treaties. ${ }^{54}$ These treaties would then form part of Australia's fulfilment of its current obligations under international law, for example under the UN Declaration on the Rights of Indigenous Peoples of 2007. This treaty-based framework would lead to a larger role for customary international law in First Nations jurisprudence in Australia. In particular, this framework would lead to customary international law being argued in Australian courts as part of the interpretation of the treaties. My proposal is hence for First Nations governance structures to be established in Australia, guided by customary international law as embodied in international law instruments. ${ }^{55}$ Most of these instruments are based on binding treaties, although some represent 'soft law' instruments. ${ }^{56}$

\footnotetext{
${ }^{52}$ In particular the judgment by Brennan J: Mabo v Queensland (No 2) (1992) 175 CLR 1, 42. Mason $\mathrm{CJ}$ and McHugh $\mathrm{J}$ also endorsed harmonising the development of Australian domestic law with the instruments of international law: at 15.

${ }^{53}$ See, for example, Commonwealth v State of Tasmania (1983) 158 CLR 1 ('Franklin Dam case') and Richardson v Forestry Commission (1988) 164 CLR 261 ('Lemonthyme case'). See also the UN Human Rights Committee decision in Toonen $v$ Australia, UN Doc CCPR/C/50/D/488/1992 (1994) for the effect of the International Covenant on Civil and Political Rights on domestic law. For a general discussion of this nexus between international and domestic law, see Hilary Charlesworth et al (eds), The Fluid State: International Law and National Legal Systems (Federation Press, 2005).

${ }^{54}$ See for example Miguel Alfonso Martinez, Special Rapporteur, Final Report on the Study of Treaties, Agreements and other Constructive Arrangements between States and Indigenous Populations, UN Doc E/CN.4/Sub.2/1999/20 (22 June 1999).

${ }^{55}$ See Garth Nettheim, Gary D Meyers and Donna Craig, Indigenous Peoples and Governance Structures: A Comparative Analysis of Land and Resource Management Rights (Aboriginal Studies Press, 2002).

${ }^{56}$ These include most resolutions and declarations of the UN General Assembly, for example, the United Nations Declaration on the Rights of Indigenous Peoples (n 34). See, however, Megan Davis, 'To Bind or Not to Bind: The United Nations Declaration on the Rights of Indigenous Peoples Five Years On’ (2012) 19 Australian International Law Journal 17.
} 
The following Part provides an example of the possible wording of a constitutional recognition, providing a platform for future treaty negotiation.

\section{A Form of Constitutional Wording}

This note proposes that a new chapter be added to the Australian Constitution. Given that the proposed constitutional recognition is intended to bestow honour and remembrance on the Aboriginal Peoples of Australia, it would be best to introduce a new, dedicated chapter (Chapter IIIA) into the Constitution for the purpose of this recognition. This approach is in line with one of the options identified by the Joint Select Committee. ${ }^{57}$

The first section of the proposed chapter would serve to remember the role played by Aboriginal and Torres Strait Islander Peoples in Australia's past, while their present role would be acknowledged in a second section that would emphasise the sui generis nature of their cultures. The future of the relationship between the Commonwealth and the Aboriginal and Torres Strait Islander Peoples would be recognised in a third section which would refer to international law standards. leading to a treaty-based framework that would increase the political, social, and economic autonomy of Australia's First Nations. Giving effect to the section $80 \mathrm{C}$ obligations below would form the backbone of the relationship between the Commonwealth and First Nations, a relationship that would later be fleshed out through negotiating separate treaties for each nation.

The proposed wording of the new chapter is as follows:

\section{Chapter IIIA Constitutional Recognition of Aboriginal and Torres Strait Islander Peoples}

80A The Commonwealth of Australia recognises the Aboriginal and Torres Strait Islander Peoples as the first occupiers of the Australian continent.

80B

The Commonwealth of Australia acknowledges the perennial and sui generis nature of Aboriginal and Torres Strait Islander cultures, and the continuing relationship of these cultures to their traditional territories.

\footnotetext{
57 Joint Select Committee Interim Report (n 29) [2.33]; Joint Select Committee Final Report (n 5) [4.14].
} 
$80 \mathrm{C}$

The Commonwealth of Australia, subject to this Constitution, shall guarantee the collective rights of the Aboriginal and Torres Strait Islander Peoples according to the universally recognised principles and norms of customary international law and international treaties and agreements of the Commonwealth of Australia.

The difference between my proposed chapter and current proposals made by the Joint Select Committee ${ }^{58}$ lies mainly in the third section, section 80C. The Committee proposals seem to derive their language from the Canadian Constitution Act, 1867, in particular section 91(24). ${ }^{59}$ The same language is found in section 51(xxvi) of the current Australian Constitution. It is submitted that the approach taken in section 91(24) is outdated. The 148 years that have followed the enactment of this subsection have seen great strides in international law on the governance of First Nations. Today, reference to international law instruments, as proposed in section $80 \mathrm{C}$ above, would be more in line with modern jurisprudence on the subject matter. Similar language to that of section $80 \mathrm{C}$ can already be seen in the Constitution of Ecuador, ${ }^{60}$ and in the Constitution of Bolivia. ${ }^{61}$ Further examples can be found in other constitutions, for example the Constitution of Russia of $1993,{ }^{62}$ and the Constitution of South Korea. ${ }^{63}$

${ }^{58}$ Joint Select Committee Final Report (n 5) [4.88] Recommendation 5. See also Nicky Jones, 'Reforming the Australian Constitution: An Overview of Recognition Proposals' in Simon Young, Jennifer Nielson, and Jeremy Patrick, Constitutional Recognition of First Peoples in Australia: Theories and Comparative Perspectives (Federation Press, 2016) 48.

59 Constitution Act 1867 (Imp) 30 \& 31 Vict, c 3, s 91: ' $\ldots$ it is hereby declared that (notwithstanding anything in this Act) the exclusive Legislative Authority of the Parliament of Canada extends to all Matters coming within the Classes of Subjects next hereinafter enumerated; that is to say, ... 24. Indians, and Lands reserved for the Indians.'

${ }^{60}$ For example, Constitution of Ecuador of 2008, art 3: 'The State's prime duties are: 1. Guaranteeing without any discrimination whatsoever the true possession of the rights set forth in the Constitution and in international instruments, especially the rights to education, health, food, social security and water for its inhabitants.'

${ }^{61}$ For example, Constitution of Bolivia of 2009, art 14(III): 'The State guarantees all people and communities, without discrimination, the free and effective exercise of the rights established in this Constitution, laws and international treaties of human rights.'

${ }^{62}$ Constitution of Russia of 1993, art 69: 'The Russian Federation shall guarantee the rights of the indigenous small peoples according to the universally recognized principles and norms of international law and international treaties and agreements of the Russian Federation.'

${ }^{63}$ Constitution of South Korea 1948, art 6(1): 'Treaties duly concluded and promulgated under the Constitution and the generally recognized rules of international law shall have the same effect as the domestic laws of the Republic of Korea.' 


\section{B Recommendations on Section 25 and Section 51(xxvi)}

Current proposals by the Joint Select Committee on the constitutional recognition of First Nations also recommend the repeal of section 25 of the current Australian Constitution. ${ }^{64}$ My recommendation, on the other hand, is not to repeal this section. As noted by a number of commentators, ${ }^{65}$ this section is inspired by the $14^{\text {th }}$ Amendment of the United States Constitution. It is intended as a penalty imposed on States that deny the vote to First Nations. ${ }^{66}$ Reference to race in this section cannot be interpreted in a negative manner. As to reference to race generally, this can be seen in many constitutions, including the Canadian Charter of Rights and Freedoms. ${ }^{67}$ The objective of removing reference to 'race' from the Australian Constitution might have great symbolic value, but no more. On the other hand, shifting the focus to section 25 , by repealing it, could detract from the essential issue of introducing a wide and dynamic constitutional recognition of Indigenous Australians. Moreover, the recommended Chapter IIIA, as worded above, would provide added guarantees (from international law treaties already endorsed by Australia) that section 25 would not be invoked in a way detrimental to Indigenous Australians.

Similar arguments militate against repealing section 51(xxvi). While the High Court decision in Kartinyeri $v$ Commonwealth ${ }^{68}$ suggests that section 51(xxvi) could be used to enact laws that discriminate against Aboriginal peoples, in practical terms this is highly unlikely. This is because, in a globalising world, the Australian approach to First Nations is likely to become more in tune with the international approach. Discrimination would be seen as very costly for Australia's role on the international stage. Again, the constitutional recognition suggested in this note, and especially that contained in proposed section $80 \mathrm{C}$, would ensure that the current section 51 (xxvi) is not used to discriminate

\footnotetext{
${ }^{64}$ Joint Select Committee Final Report (n 5) [3.19] Recommendation 3.

${ }^{65}$ See Anne Twomey, 'An Obituary for Section 25 of the Constitution' (2012) 23(2) Public Law Review 125.

${ }^{66}$ Ibid.

${ }^{67}$ Canada Act 1982 (UK) c 11, sch B pt I ('Canadian Charter of Rights and Freedoms') s 15(1) 'Every individual is equal before and under the law and has the right to the equal protection and equal benefit of the law without discrimination and, in particular, without discrimination based on race, national or ethnic origin, colour, religion, sex, age or mental or physical disability. (2) Subsection (1) does not preclude any law, program or activity that has as its object the amelioration of conditions of disadvantaged individuals or groups including those that are disadvantaged because of race, national or ethnic origin, colour, religion, sex, age or mental or physical disability.'

68 (1998) 195 CLR 337 ('Hindmarsh Island Bridge case').
} 
against Indigenous Australians; the proposed section enshrines in the Constitution the international law guarantees already endorsed by Australia.

In fact, the combination of the proposed section $80 \mathrm{C}$ and the current section 51(xxvi) would be the ideal basis for the formation of treaties with Australia's First Nations. Section 80C would inform the content of such treaties, while the exclusive power of the Commonwealth under section 51(xxvi) would create efficiency gains produced by a homogeneous approach across all Australian states and territories.

Furthermore, as found by the Expert Panel and the Joint Select Committee, a repeal of section 51(xxvi) would need to be accompanied by new Commonwealth legislation to remove the risk of invalidating other legislation relating to Aboriginal and Torres Strait Islander Peoples. ${ }^{69}$ Given the low risks posed by leaving this subsection as it is, there is little justification for its repeal. Its reformulation is equally problematic. Proposals for a reformulation of section 51(xxvi) risk being seen by voters as a 'special treatment' of First Nations. ${ }^{70}$

\section{Expert Panel's Proposed New Section 116A and Section 127A}

As to the introduction of sections $116 \mathrm{~A}$ and $127 \mathrm{~A},{ }^{71}$ the recognition approach proposed in this note makes these sections redundant. Given the formulation presented in proposed section $80 \mathrm{C}$, namely the invocation of international law instruments (already endorsed by Australia) that prohibit discrimination (for example, article 2 of the UN Convention on the Elimination of All Forms of

${ }^{69}$ Joint Select Committee Interim Report (n 29) [2.26]-[2.29]. But cf Joint Select Committee Final Report (n 5) ch 3.

70 Joint Select Committee Interim Report (n 29) [2.18]-[2.27]; Joint Select Committee Final Report (n 5) ch 3.

71 The draft text of these sections is as follows:

'Section 116A Prohibition of racial discrimination

(1) The Commonwealth, a State or a Territory shall not discriminate on the grounds of race, colour or ethnic or national origin.

(2) Subsection (1) does not preclude the making of laws or measures for the purpose of overcoming disadvantage, ameliorating the effects of past discrimination, or protecting the cultures, languages or heritage of any group.'

'Section 127A Recognition of languages

(1) The national language of the Commonwealth of Australia is English.

(2) The Aboriginal and Torres Strait Islander languages are the original Australian languages, a part of our national heritage.' 
Racial Discrimination; and article 7 of the Universal Declaration of Human Rights), and that ensure the recognition of Indigenous languages (for example article 13 of the UN Declaration on the Rights of Indigenous Peoples), it should be clear that re-inventing the wheel through sections such as 116A and 127A would be not only a narrow approach, but one that is highly inefficient.

\section{iv Conclusion}

This note advocates for a constitutional recognition of Australia's First Nations consistent with the objectives of efficiency and equality. In this sense, it presents an ideal-type model for recognition. The analytical approach uses stylised constitutional recognition along two dimensions: dynamic (-static) recognition and wide (-narrow) recognition. The first dimension reflects the evolution of First Nations' wellbeing through continuous improvement in their affairs, unhindered by the inertia of constitutional amendment processes or by ossified constitutional lists of enumerated rights. The second dimension is a proxy for legal pluralism and concerns the nature of the rights flowing from any recognition, and whether the rights are assimilated under Western jurisprudence or accepted as sui generis in nature.

An optimal recognition is one that is efficient and equitable. To achieve a dynamic recognition, the actual rights should not be enumerated in the Constitution, but left for legislative intervention based on the Constitution, as well as further development through the courts. This would be consistent with Mabo, which is about the emergence of a school of constitutional interpretation. To secure a wide recognition, a 'plurinational' approach would be needed, inspired by international law instruments such as the ILO Indigenous and Tribal Peoples Convention, $1989^{72}$ and the United Nations Declaration on the Rights of Indigenous Peoples. ${ }^{73}$ To achieve this optimal design, recognition would need to be guaranteed by universal international law principles in relation to First Nations, and minorities generally.

Here it is important to remind ourselves of an explicit assumption made earlier, namely that the government has the political will to give effect to this recognition. This political will was presented as an essential precondition to the desired outcome. It would be of interest to see now what would happen if we relax this assumption. It is no secret that the Commonwealth has done very little in the way of respecting its commitments to the United Nations. The treatment

\footnotetext{
${ }^{72}$ See above $\mathrm{n} 39$.

${ }^{73}$ See above $n 38$.
} 
of asylum seekers is a case in point. ${ }^{74}$ In fact, given the merely symbolic subnational recognition of First Nations in state constitutions, it is difficult to imagine the Commonwealth respecting its commitment to take international norms and principles into account in its dealings with Indigenous Australians. Put simply, there is not enough political pressure from First Nations to alter the position of the States, and hence to put pressure on the Commonwealth, even to the extent seen in Canada in which the demographic and geographic profiles of First Nations are similar to those in Australia. ${ }^{75}$

However, probably the best means by which First Nations could bring about a dynamic and wide recognition of their rights is not political, but economic. Socio-economic benefits may accrue from an 'optimal' recognition as discussed above. The Commonwealth should extrapolate lessons learned in other jurisdictions, most notably in New Zealand and the Māori contribution to the economy of that country (triggered through Treaty of Waitangi settlements). ${ }^{76}$

It would be useful to see the analytical model enhanced by application to a larger sample of countries, and potentially with time-series data that tracks the wellbeing of First Nations before and after their constitutional recognition. The question is whether constitutional recognition has an identifiable causal link with improvement in the well-being of Indigenous peoples. In other words, are First Nations better off where there is recognition? It will be necessary to develop a composite measure capable of capturing wellbeing, for example through an assessment of the economic contribution by First Nations to the national GDP, although such measures only poorly assess wellbeing. There might also be a need to bolster the model with more analytical dimensions that capture further nuances in constitutional recognition between different jurisdictions. A centralised national Australian monitor of these variables would be critical to conducting a 'health check' on the effects of any recognition that finally materialises, and how the same can be optimised.

\footnotetext{
${ }^{74}$ In particular, the UN Special Rapporteur on Torture has found Australia's policies on asylum seekers to be in violation of the UN Convention against Torture and Other Cruel, Inhuman or Degrading Treatment or Punishment which Australia signed in 2009 but did not ratify. See 'UN Finds Australia's Treatment of Asylum Seekers Violates the Convention against Torture', Human Rights Law Centre (News Report, 6 March 2015) <https://www.hrlc.org.au/news/unfinds-australias-treatment-of-asylum-seekers-violates-the-convention-against-torture> .

${ }^{75}$ Canada and New Zealand are discussed in detail in Gussen (n 1).

${ }^{76}$ See Ganesh Nana, Fiona Stokes and Wilma Molano, The Māori Economy, Science and Innovation: Potential Opportunity and Value (Business and Economic Research, Ltd, 2011).
} 